\title{
A Review on Response of Pigeonpea to Different Drip Fertigation Levels
}

\author{
S. S. Thakare*, L. A. Mohurle, S. U. Kakade, J. P. Deshmukh, \\ A.N. Paslawar and N. D. Parlawar \\ Department of Agronomy, Dr. Panjabrao Deshmukh Krishi Vidyapeeth, \\ Akola, Maharashtra, India \\ *Corresponding author
}

\begin{abstract}
A B S T R A C T
India has virtual monopoly in pigeonpea production accounting to $90 \%$ of world's total production but the average productivity is relatively low due to terminal moisture stress and the production is not adequate to meet the demand of increasing population. To meet the said demand pigeon pea productivity has to be increased. There is a need for judicious management of available water and plant nutrients through different fertilizers to increase the productivity and to reduce the production costs of pigeonpea. Application of fertilizer at appropriate stages of crop growth ensures a regular flow of both water and nutrients resulting in increased growth rates and higher yields. Drip fertigation method is an option for efficient use of water and nutrients through improvement in crop yield per unit volume of water and nutrients used. Fertilizer use efficiency up to $95 \%$ can be achieved through drip fertigation. In the present paper, as reported by different research workers throughout world drip fertigation in pigeon pea saves $30 \%$ to $70 \%$ of water, significant fertilizer savings of $20-60 \%$ increases yield by $20 \%$ to $90 \%$ and results in higher water use efficiency from $35.5 \%$ to $50.8 \%$ as compared with conventional method resulting in reduction of cost of cultivation.
\end{abstract}

\section{Introduction}

Pigeonpea (Cajanus cajan (L.) Millsp.) is nutritionally well balanced and is an excellent source of proteins (20-30\%) (Snapp et al., $2003)^{[37]}$, which almost three times that of cereals. India has virtual monopoly in pigeonpea production accounting to $90 \%$ of world's total production. Generally, pigeonpea is grown under rain fed conditions in tropical and sub-tropical regions under poor resource conditions of marginal soils, low and erratic rainfall distribution or intercropped with other crops like sorghum or cotton during rainy season in Maharashtra. In spite of adoption of high yielding varieties during rainy season the average productivity is very less due to terminal moisture stress. The demand for pulses is increasing due to increasing population. To meet the said demand pigeonpea productivity has to be increased. The availability of adequate, timely and assured supply of water is an important determinant of agricultural productivity. 
Agriculture is by far the largest $(81 \%)$ water consumer in India and hence more efficient use of water in agriculture needs to be the top most priority (INCID, 2006) ${ }^{[15]}$. Water input per unit irrigated area will have to be reduced in response to water scarcity and environmental concerns (WRI, 2007) ${ }^{[45]}$. Due to growing high cost of synthetic fertilizers, increasing dependence on fertilizer imports, non-uniform application of irrigation water, scarcity of water at terminal growth stages, decline in crop response to fertilizer, soil inadequate and unbalanced fertilizer use under which declining crop response to applied fertilizers through conventional fertilizer application. Therefore, there is a need for judicious management of available water and plant nutrients through different fertilizers to increase the productivity and to reduce the production costs of pigeonpea. For optimum use of fertilizers farmer needs to know when to apply (regarding the time of application), how to apply (method of application) and how much to apply (quantity for application) during different growth stages of pigeonpea. These goals can be achieved by adopting the high efficient technologies like drip fertigation.

Fertilizer use efficiency up to $95 \%$ can be achieved through drip fertigation. Studies reveal significant fertilizer savings of $20-60 \%$ and $8-41 \%$ increase in yields of field and vegetable crop due to fertigation. Drip fertigation remarkably increase the efficiency of the applied fertilizer and water and saving cost, labour and energy resulting in reduced cost of cultivation. Application of fertilizer at appropriate stages of crop growth ensure a regular flow of both water and nutrients resulting in increased growth rates and higher yields. Fertigation can be done at predetermined schedule according to the developmental and physiological stage of the crop. It also improves availability of nutrients and their uptake by plants. Combined application of water and fertilizer through fertigation accentuate the scope for increasing productivity and efficient use of water and nutrients.

To meet out the requirement the only ways is to increase the production and productivity for that drip irrigation is the best option. Green revolution made our nation selfsufficient in case of cereals but we still deficient in pulse production. To get rid of this bulky expenditure, it is necessary to bring improvement in pigeonpea production. Development of high yielding, disease and pest resistance varieties, irrigation sources and expensive fertilizers had been major thrust in pigeonpea development programme in the country. Therefore, drip irrigation and fertigation for economic management of the crop to get maximum production with minimum cost may useful for the farmers. Drip irrigation and fertigation increases efficient use of water and fertilizers produces higher yield, improve quality of pigeonpea and protect environment. Chemical fertilizers are the real assets if they applied whenever needed by the crop in appropriate form and amount.

\section{Importance of nutrient and fertigation for legumes}

Nitrogen, phosphorus and potassium are the three major and primary nutrients required for the crop growth and productivity. Legumes fix their own nitrogen if proper inoculants and sufficient amounts of phosphorus, potassium, sulphur and micronutrients are present. Therefore, small amount of nitrogen is very important during early phase i.e seedling stage. Phosphorus is necessary for energy storage and transfer and is essential for vigorous growth and seed development. It enhances crop maturity and quality, especially in grain crops. Potassium maintains water balance and therefore stalk strength. In 
addition, potassium promotes energy generation which is required for translocation of nutrients in the plant, nitrogen uptake and protein synthesis. Crops that are potassium deficient result in low total nitrogen uptake, yield and protein. Pigeonpea takes up relatively small amounts of nutrients early in the season, but as it grows and develops, the daily rate of nutrient uptake increases and it requires an adequate supply of nutrients at each developmental stage for optimum growth. High yielding long duration pigeonpea removes substantial nutrients from the soil. Considering the importance of $\mathrm{N}$, $\mathrm{P}_{2} \mathrm{O}_{5}$ and $\mathrm{K}_{2} \mathrm{O}$ fertilization to pigeonpea. Drip irrigation and fertigation will help to increase area under pigeonpea cultivation under water scarcity condition. Which will help to increase the branches/plant, nodule/plant, flower/plant which will ultimately increases shelling percentage and yield. In this respect, fertigation proposed as a means to increase efficient use of water and fertilizer to increase yield, protect environment and sustained irrigated agriculture.

\section{Need of nitrogen}

Application of adequate supply of nitrogen is usually associated with increased yield and protein content of pigeonpea. Pulses can meet their own nitrogen requirement by symbiotic fixation of atmospheric nitrogen. Balanced supply of nitrogenous fertilizer not only improves crop yield and nutrient uptake but also nodulation in pigeonpea. However, a starter dose of nitrogen and adequate phosphorus are considered as essential for obtaining optimum yield. Application of 30 $\mathrm{kg} \mathrm{N} \mathrm{ha}{ }^{-1}$ produced significantly higher yield through higher number of pods in pigeonpea. Inoculation of rhizobium significantly increased the number of nodules per plant and grain yield by application of $20 \mathrm{~kg} \mathrm{~N} \mathrm{ha}{ }^{-1}$. Split application of 50 per cent $\mathrm{N}$ as basal + 50 per cent $\mathrm{N}$ at branching proved to be the most effective for realizing higher yield in french bean (Ghosal and Bahl, 2000) ${ }^{[11]}$.

\section{Need of phosphorus}

The deficiency of phosphorus to the plant is due to its fixation in soil. Based on the study, it is suggested that phosphorus plays an important role in nitrogen fixation through an effective translocation of phosphorus to the leaf. Pigeonpea is a highly exhaustive pulse crop and requires higher amount of $\mathrm{P}$ nutrition for optimum production (Avinash Kumar and Kushwaha, 2006) ${ }^{[6]}$. Among all the elements required by a plant, phosphorus is one of the most important nutrients for crop production and emphasis is to be given on the efficient use of $\mathrm{P}$ fertilizer for sustainable crop production (Ryan, 2002) ${ }^{[36]}$. Respiration and photosynthesis are both reduced in phosphorus deficient plants. Stress from phosphorus deficiency at early growth stage has considerable negative influence on crop production (Grant et al., 2001) ${ }^{[3]}$. Adhikary and Sarkar (2000) ${ }^{[1]}$ reported that the seed yield of pigeonpea increased significantly with increasing levels of $\mathrm{P}$ upto $60 \mathrm{~kg} \mathrm{P}_{2} \mathrm{O}_{5}$ ha- ${ }^{1}$. Phosphorous is highly immobile in soils and is often a limiting nutrient. Phosphorus deficient plants suffer from reduced leaf expansion, reduced surface size and reduced number of leaves.

\section{Need of potassium}

Potassium is known to play a vital role in osmoregulation and activation of several enzymes. Besides this, it helps the plant to adapt under terminal moisture stress/abiotic stresses mostly experienced during reproductive stage. Potassium is involved in many physiological processes which influence crop quality, it activates more than 60 enzymes systems, aids photosynthesis, favours high energy status, regulates opening of leaf stomata, maintains cell turgor, 
promotes water uptake, regulates nutrient translocation, favours carbohydrate transport and hence enhance protein and starch synthesis (Brar and Imas, 2010) ${ }^{[6]}$. Potassium is less mobile than nitrate and distribution in the wetted volume may be more uniform due to interaction with soil binding sites.

Grain yield of pigeonpea was increased significantly with the application of potassium upto $60 \mathrm{~kg} \mathrm{~K}_{2} \mathrm{O} \mathrm{ha}{ }^{-1}$ by 29 per cent and the agronomic efficiency of potash applied to pigeonpea was $6.6 \mathrm{~kg} \mathrm{~kg}^{-1} \mathrm{~K}_{2} \mathrm{O}$ (Tiwari et al., 2012) ${ }^{[40]}$. Anilkumar (2001) ${ }^{[3]}$ reported that potassium uptake was significantly higher (105.14 kg ha ${ }^{-1}$ ) with 100 per cent water needed at $0.8 \mathrm{IW} / \mathrm{CPE}$ ratio than 75 per cent of water.

\section{Effect of drip fertigation on growth and yield}

Kantwa et al., (2005) ${ }^{[18]}$ revealed that phosphorus fertilization at $40 \mathrm{~kg} \mathrm{P}_{2} \mathrm{O}_{5} \mathrm{ha}^{-1}$ being at par with $80 \mathrm{~kg} \mathrm{P}_{2} \mathrm{O}_{5} \mathrm{ha}^{-1}$ increase plant height (152.2) and at $40 \mathrm{~kg} \mathrm{P}_{2} \mathrm{O}_{5} \mathrm{ha}^{-1}$ and 154.5 at $80 \mathrm{~kg} \mathrm{P}_{2} \mathrm{O}_{5} \mathrm{ha}^{-1}$ ) and phosphorus fertilization at $40 \mathrm{~kg} \mathrm{P}_{2} \mathrm{O}_{5} \mathrm{ha}^{-1}$ being at par with $80 \mathrm{~kg} \mathrm{P}_{2} \mathrm{O}_{5} \mathrm{ha}^{-1}$ increase number of pod plant $^{-1}$ (160.0 and 161.9 at $40 \mathrm{~kg}$ and $80 \mathrm{~kg}$ $\mathrm{P}_{2} \mathrm{O}_{5}$ respectively) over unfertilized pigeonpea in sandy loam soils of New Delhi.

The irrigation significantly increased the plant height over control in pooled analysis. The mean increased over control at final stage was to the tune of $3.21 \%$ under 0.30 and $6.95 \%$ under $0.60 \mathrm{IW} / \mathrm{CPE}$ ratio. Plant irrigated in $0.60 \mathrm{IW} / \mathrm{CPE}$ ratio was significantly taller than those grown under $0.30 \mathrm{IW} / \mathrm{CPE}$ ratio. Irrigation markedly increased the bearing expressed as number of pod plant ${ }^{-1}$, but the significant increase was obtained only upto $0.30 \mathrm{IW} / \mathrm{CPE}$ ratio. It was increased upto $48.10 \%$ against no irrigation reported by Gajera and Ahlawat (2006) ${ }^{[10]}$.
A field experiment was conducted at Chitrakoot (MP) by Avnish Kumar and Kushwaha (2006) ${ }^{[5]}$ reported that the growth attributes like plant height of pigeonpea was maximum and significantly higher $(117.1 \mathrm{~cm})$ at $80 \mathrm{~kg} \mathrm{P}_{2} \mathrm{O}_{5}$ than $20 \mathrm{~kg} \mathrm{P}_{2} \mathrm{O}_{5} \mathrm{ha}^{-1}(108.7$ $\mathrm{cm})$. However, it was at par with $60 \mathrm{~kg} \mathrm{P}_{2} \mathrm{O}_{5}$ $(118.8 \mathrm{~cm})$ and number of pod plant $^{-1}$ were maximum and significantly higher with phosphorus application of $80 \mathrm{~kg} \mathrm{P}_{2} \mathrm{O}_{5}$ ha ${ }^{1}$ (121.3) than $20 \mathrm{~kg} \mathrm{P}_{2} \mathrm{O}_{5} \mathrm{ha}^{-1}$ (102.3) and 10 $\mathrm{kg} \mathrm{P}_{2} \mathrm{O}_{5} \mathrm{ha}^{-1}$ (109.8). However, it was at par with $60 \mathrm{~kg} \mathrm{P}_{2} \mathrm{O}_{5}(121.7 \mathrm{~cm})$ application in sandy loam soil at Satna.

Pigeonpea irrigated at specific crop growth stages of flowering and pod development produced better leaf area index and resulted in higher CGRs contributing to more dry matter reported by Pothalkar (2007) ${ }^{[30]}$.

The application of $60 \mathrm{~kg} \mathrm{P}_{2} \mathrm{O}_{5} \mathrm{ha}^{-1}(203.0 \mathrm{~cm})$ being at par with $45 \mathrm{~kg} \mathrm{P}_{2} \mathrm{O}_{5} \mathrm{ha}^{-1}(201 \mathrm{~cm})$ over no phosphorus application $(162.2 \mathrm{~cm})$, $15 \mathrm{~kg} \mathrm{P}_{2} \mathrm{O}_{5} \mathrm{ha}^{-1}(178.3 \mathrm{~cm})$ and $30 \mathrm{~kg} \mathrm{P}_{2} \mathrm{O}_{5} \mathrm{ha}^{-}$ ${ }^{1}(190.5 \mathrm{~cm})$. Also recorded application of 60 $\mathrm{kg}_{2} \mathrm{O}_{5} \mathrm{ha}^{-1}$ being at par with $45 \mathrm{~kg} \mathrm{P}_{2} \mathrm{O}_{5} \mathrm{ha}^{-1}$ recorded significantly more number of primary branches plant ${ }^{-1}$ (20.8) over $30 \mathrm{~kg}$ (15) and $15 \mathrm{~kg}$ (11.5) $\mathrm{P}_{2} \mathrm{O}_{5} \mathrm{ha}^{-1}$. Application of $60 \mathrm{~kg} \mathrm{P}_{2} \mathrm{O}_{5} \mathrm{ha}^{-1}(159.6 \mathrm{~g})$ being at par with $45 \mathrm{~kg} \quad \mathrm{P}_{2} \mathrm{O}_{5} \quad \mathrm{ha}^{-1}(155.9 \mathrm{~g})$ recorded the maximum dry matter plant ${ }^{-1}$ over no phosphorus application (139.8 g), $15 \mathrm{~kg} \mathrm{P}_{2} \mathrm{O}_{5}$ $\mathrm{ha}^{-1}(144 \mathrm{~g})$ and $30 \mathrm{~kg} \mathrm{P} \mathrm{O}_{5} \mathrm{ha}^{-1}(147.6 \mathrm{~g})$ in sandy clay loam soils at BHU, Varanasi reported by Singh and Yadav (2008) ${ }^{[39]}$.

Anil Jain (2010) ${ }^{[2]}$ reported that by adopting drip irrigation in pigeonpea at farmer's field, the highest seed yield of $33 \mathrm{q} \mathrm{ha}^{-1}$ was recorded in Hingne village of Jalgaon district in Maharashtra.

Mahalakshmi et al., (2011) ${ }^{[21]}$ revealed that pigeonpea under drip irrigation with 0.8 Epan 
throughout the crop period recorded higher plant height $(61.6 \mathrm{~cm})$, higher total dry matter production $\left(3731 \mathrm{~kg} \mathrm{ha}^{-1}\right)$ at harvest stage.

Vimalendran and Latha (2014) ${ }^{[44]}$ revealed that drip irrigation at $100 \%$ WRc with fertigation at $125 \%$ RDF through WSF registered significantly highest grain yield of 2812 and $2586 \mathrm{~kg} \mathrm{ha}^{-1}$ during 2011-12 and 2012-13, respectively.

Manikandan and Sivasubramaniam (2015) ${ }^{[23]}$ reported that plant height at 90 DAS which was higher observed with fertigation using $100 \%$ SRDF as WSF and foliar feeding with $0.5 \%$ Zinc Sulphate that resulted in higher values of $157.4 \mathrm{~cm}$ and $140.7 \mathrm{~cm}$ at 90 DAS in Kharif and summer, respectively. Plant height was increased by $25.4 \%$ and $28.7 \%$ in Kharif and summer, respectively with similar treatment combinations. The results also clearly indicated that the water-soluble fertilizers played a significant role in increasing the plant height. Interaction of surface drip fertigation and foliar spray significantly influences the number of branches. The result clearly indicated that the combination of $100 \%$ SRDF as WSF + foliar feeding with $0.5 \%$ of $\mathrm{ZnSO}_{4}$ recorded maximum number branches 18.3 in kharif and 14.3 in summer at 90 DAS with 50 and $81 \%$ respectively higher compared to $50 \%$ SRDF as WSF in kharif and summer respectively. The result clearly indicated that the water soluble fertilizers played a significant role in increasing number of branches. Higher number of pods plant ${ }^{-1}$ (415 in Kharif and 368 in summer) with $12.8 \%$ higher number in Kharif over summer.

\section{Effect of drip fertigation on yield attributes and yields of pigeon pea}

Goud and Kale (2010) ${ }^{[12]}$ revealed that the application of 18:46:20:20 kg N: P; K; S ha recorded improvement in growth attributes like more plant height $(187.6 \mathrm{~cm})$ over 9:15:10:10 kg N: P: K: S ha ${ }^{-1}(181.2 \mathrm{~cm})$, more number of branches plant ${ }^{-1}$, recorded high dry matter accumulation(135.49 $\mathrm{g}$ plant ${ }^{1}$ ) over 9:13:10:10 kg N:P:K:S ha ${ }^{-1}(126.70 \mathrm{~kg})$ plant $^{-1}$, more number of pod plant ${ }^{-1}$ in pigeonpea in medium clayey soil of Akola.

Parmodh Sharma et al., (2012) ${ }^{[27]}$ reported that furrow irrigation with $100 \%$ RDF recorded significantly lower number of pods plant $^{-1}$ (61.8) than all other treatments may be due to leaching of nutrients and moisture variations between two successive irrigations with lower uptake of nutrients.

In direct sown pigeonpea ( $\mathrm{CO} 6$ ) at single row per lateral with 10 split application of $\mathrm{N}$ and $\mathrm{K}$ through drip fertigation +100 per cent WRc recorded the highest grain yield (1486 $\mathrm{kg} \mathrm{ha}^{-1}$ ), over different spacing in transplanted pigeon pea in the Western Zone of Tamil Nadu noted by Latha et al., (2012) ${ }^{[20]}$

Praharaj (2013) ${ }^{[34]}$ reported that similar to furrow or flood irrigation, 1-2 irrigations by appropriate micro-irrigation schedules at the most critical stages has proven highly productive in most of the pulses. Dripfertigation in long-duration pigeonpea at branching and pod development with $\mathrm{N}$ and $\mathrm{K}$ at one-fourth of recommended dose (of 20: 20 $\mathrm{kg} \mathrm{ha}^{-1}$ ) in 5 splits in the above stages (along with $1 / 2$ of $\mathrm{N}$ and $\mathrm{K}+$ full $\mathrm{P}$ at sowing) gave higher yield and returns.

Praharaj et al., (2014) ${ }^{[33]}$ in an experiment carried out during 2010-12, involving precision irrigation through drip-fertigation schedules, revealed that a potential seed yield of $3,708 \mathrm{~kg} \mathrm{ha}^{-1}$ was realized under dripfertigation at branching only.

Chandra Sekhar et al., (2014) ${ }^{[7]}$ reported that significantly more number of pods plant ${ }^{-1}$ (77.9) were recorded with drip nutrigation of 
$100 \% \mathrm{~N}+100 \% \mathrm{P}_{2} \mathrm{O}_{5}$ over $60 \% \mathrm{~N}$ with 50 $\%$ or $100 \% \mathrm{P}_{2} \mathrm{O}_{5}$ and application of $100 \%$ RDF in conventional method under drip irrigation and was on par with drip nutrigation of $100 \% \mathrm{~N}$ or $80 \% \mathrm{~N}$ with $50 \% \mathrm{P}_{2} \mathrm{O}_{5}$ and 80 $\% \mathrm{~N}+100 \% \mathrm{P}_{2} \mathrm{O}_{5}$. The higher number of pods with drip nutrigation at higher dose of nutrients may be due to availability of sufficient nitrogen and phosphorus nutrients to meet the crop requirement resulted in enhanced photosynthetic activity due to higher leaf area index and better translocation of assimilates from source to sink (floral parts). Significantly higher seed yield $(772 \mathrm{~kg}$ $\mathrm{ha}^{-1}$ ) of rabi pigeonpea was recorded with drip nutrigation of $100 \%\left(40 \mathrm{~kg} \mathrm{ha}^{-1}\right) \mathrm{N}+100 \%$ $\mathrm{P}_{2} \mathrm{O}_{5}\left(50 \mathrm{~kg} \mathrm{ha}^{-1}\right)$ and was on par with $100 \%$ $\mathrm{N}+50 \% \mathrm{P}_{2} \mathrm{O}_{5}$ and $80 \% \mathrm{~N}+100 \% \mathrm{P}_{2} \mathrm{O}_{5}$. These treatments were significantly higher over $80 \%$ or $60 \% \mathrm{~N}$ with $50 \% \mathrm{P}_{2} \mathrm{O}_{5}, 60 \%$ $\mathrm{N}+100 \% \mathrm{P}_{2} \mathrm{O}_{5}$, application of $100 \% \mathrm{RDF}$ (40:50:20 kg N, $\mathrm{P}_{2} \mathrm{O}_{5} \quad \& \quad \mathrm{~K}_{2} \mathrm{O} \quad \mathrm{ha}^{-1}$ ) in conventional method either under drip or furrow irrigation. Significantly lower seed yield $\left(515 \mathrm{~kg} \mathrm{ha}^{-1}\right)$ and total dry matter (2523 $\mathrm{kg} \mathrm{ha}^{-1}$ ) was recorded with $100 \% \mathrm{RDF}$ in conventional method with furrow irrigation. There were no significant difference in seeds $\operatorname{pod}^{-1}$ of rabi pigeonpea due to different levels of $\mathrm{N} \& \mathrm{P}_{2} \mathrm{O}_{5}$ nutrigation, drip irrigation and furrow irrigation treatments. There were no significant difference in seeds pod $^{-1}$ of rabi pigeonpea due to different levels of $\mathrm{N} \& \mathrm{P}_{2} \mathrm{O}_{5}$ nutrigation, drip irrigation and furrow irrigation treatments. Harvest index (HI) of rabi pigeonpea $(20.54 \%)$ recorded with $100 \%$ RDF in conventional method under furrow irrigation was on par with drip nutrigation of $60 \% \mathrm{~N}$ with $50 \% \mathrm{P}_{2} \mathrm{O}_{5}$, or $100 \% \mathrm{P}_{2} \mathrm{O}_{5}$ and $80 \% \mathrm{~N}$ with $100 \% \mathrm{P}_{2} \mathrm{O}_{5}$ and was significantly higher over other drip nutrigation and RDF applied in convention method under drip irrigation treatments.

Manikandan \& Sivasubramaniam (2014) ${ }^{\text {[22] }}$ revealed that higher number of pods plant $^{-1}$
(415 in Kharif and 368 in summer) with 12.8 $\%$ higher number in Kharif over summer. This might be due to enhancement in growth and yield parameters as well as uptake of nutrients by this crop under drip fertigation. Among the treatment combinations, Seed yield $\left(\mathrm{kg} \mathrm{ha}^{-1}\right)$ was higher with $100 \%$ SRDF as WSF+ $0.5 \%$ Zinc Sulphate recorded maximum in Kharif (1416 kg ha ${ }^{-1}$ ) and in Summer (1251 kg ha ${ }^{-1}$ ) by $40.2 \%$, 48.0 per cent higher seed yield compared to $50 \%$ SRDF as WSF + 100 ppm humic acid and $41.6 \%, 47.2$ per cent higher over the control plot during Kharif and Summer, respectively.

Vimalendran and Latha (2016) ${ }^{[43]}$ showed that among the drip irrigation and fertigation levels, pigeonpea crop receiving drip irrigation at $100 \% \mathrm{WRc}$ with fertigation at $125 \%$ RDF through WSF registered significantly highest grain yield of 2812 and $2586 \mathrm{~kg} \mathrm{ha}^{-1}$ during 2011-12 and 2012-13, respectively by 45 to $47 \%$ higher over surface irrigation method with recommended dose of fertilizers through conventional method of application (1908 and $1794 \mathrm{~kg}$ ha $\left.{ }^{1}\right)$. Thus grain yield were highest in drip irrigation at $100 \% \mathrm{WRc}+$ fertigation $125 \%$ RDF through water soluble fertilizers.

The twice drip-fertigated plots also had higher yield attributes like pods plant ${ }^{-1}$. A single supplementary irrigation $(20 \mathrm{~mm}$ water through 5 splits) by drip-fertigation with half of $\mathrm{N}+\mathrm{K}$ fertilizers at branching stage could result in realization of additional grain yield to the tune of $19.6 \%$ (with two years' mean grain yield of $3419 \mathrm{~kg} \mathrm{ha}^{-1}$ ) in comparison to plots where pigeonpea was grown under rainfed condition. In addition, the plots where drip-fertigation was applied at both critical stages (branch and pod formation) of the crop (3468 $\mathrm{kg} \mathrm{ha}^{-1}$ ) out-yielded significantly over improved practice (furrow irrigation with a mean grain yield of $3262 \mathrm{~kg} \mathrm{ha}^{-1}$ ) during the second year $(9.4 \%)$ and in pooled data 
$(6.3 \%)$. here the function of fertigation $(\mathrm{N} \& \mathrm{~K})$ at critical stages was also evident from the difference in grain yield(s) obtained with drip at both branch and pod development (or drip at branch alone) vis-a-vis furrow irrigated plots. As a result, significantly higher harvest index (32\%) was analyzed with drip-fertigation at both branching and pod development over that in rainfed control $(29.6 \%)$ which reiterated the fact that drip fertigation both at branching and pod development had a positive effect on crop growth, development and consequently on grain yield (as it was enhanced over both rainfed and irrigated control) reported by Praharaj et al., $(2017)^{[31]}$.

Kakade et al., (2017) ${ }^{[17]}$ concluded that Drip fertigation with $125 \% \mathrm{~N}$ and $100 \% \mathrm{P} \& \mathrm{~K}$ in five splits found to be best treatment for improving growth attributes, maximizing the yield and beneficial in increasing the productivity and economic returns of Pigeonpea.

\section{Nutrient uptake and nutrient dynamics}

Singh et al., (2012) ${ }^{[38]}$ reported that total nutrient uptake by pigeonpea depends on biomass produced, which will vary with season, variety, soil, nutrient status and cultural practices. The right combination of water and nutrients plays a vital role for enhancing yield and quality of the produce. Under drip fertigation, availability of N, P and $\mathrm{K}$ were found to be higher in the root zone area.

Nitrogen and potassium moved laterally from a point source up to $15 \mathrm{~cm}$ and vertically up to $15-25 \mathrm{~cm}$ and $\mathrm{P}$ moved $5 \mathrm{~cm}$ both laterally and vertically and thereafter dwindled. Fertigation frequency enabled reduction in the concentration of immobile elements such as $\mathrm{P}, \mathrm{K}$ and trace elements in irrigation water.
A study was conducted by Anitta Fanish et al., (2013) ${ }^{[4]}$ on the influence of drip fertigation levels in maize to evaluate comparative performance of water soluble fertilizers with normal fertilizers and the results revealed that water soluble fertilizers (Mono ammonium phosphate and multi-K) performed better than conventional fertilizers (urea and muriate of potash) on growth, yield and nutrient uptake.

A field experiment was carried out by Kakade et al., (2018) ${ }^{[16]}$ and they reported that NUE showed a declining trend with increasing level of N, P and K, but higher NUE in drip fertigation was observed than conventional method of fertilizer application. As a consequence of better nutrient uptake and WUE, drip fertigation at 125:100:100 per cent recommended dose of NPK ha ${ }^{-1}$ had recorded higher pigeon-pea seed yield of $3866 \mathrm{~kg} \mathrm{ha}^{-1}$. It could be concluded that application of 125:100:100 per cent recommended dose of $\mathrm{N}, \mathrm{P}$ and $\mathrm{K}$ in five splits found to be best for better uptake of nutrients, WUE and maximizing the pigeon pea yield through fertigation.

\section{Effect of drip fertigation on water saving and water use efficiency}

Water use efficiency is the yield of marketable crop produced per unit of water used in evapotranspiration. Micro irrigation could play a key role in higher productivity and increased water use efficiency besides fulfilling sustainability mandates with economy in use.

Patil et al., (2008) ${ }^{[29]}$ stated that scheduling of drip irrigation in hybrid cotton at 50 per cent potential evapotranspiration throughout the crop growth period would save 50 per cent irrigation water and enhanced WUE (53.2 g $\mathrm{ha}^{-1} \mathrm{~cm}^{-1}$ ) and cotton productivity without affecting quality on a medium black soil and 
pointed out that under water scarcity area or low rainfall years, drip irrigation is better than alternate furrow irrigation method for obtaining higher water use efficiency and yield.

Irrigation water use efficiency was increased by 89 per cent over surface irrigation when scheduling was done following the 70-70-60 per cent of field capacity during each of the three major growth stages, respectively in cotton (Nazirbay et al., 2003) ${ }^{[26]}$.

Duraisamy and Manickasundaram (2008) ${ }^{[9]}$ have reported that scheduling of irrigation to perennial pigeonpea at $0.45 \mathrm{IW} / \mathrm{CPE}$ ratio accounted for a water saving of 16 and 32 per cent as compared to irrigation at 0.6 and 0.75 IW/CPE ratio. Irrigation scheduling at 1.2 ETc with application of the fertilizer in $80 \%$ of irrigation time could save water by $27.2 \%$ and increase the grain yield by $6.7 \%$, compared to the conventional methods.

Muthukrishnan and Anitta Fanish (2011) ${ }^{[25]}$ noticed that drip irrigation helped to save water upto 43.65 per cent compared to surface irrigation method.

Among the irrigation levels, drip irrigation scheduled at 0.6 Epan resulted in higher WUE $\left(122 \mathrm{~kg} \mathrm{ha}^{-1} \mathrm{~mm}^{-1}\right)$ and the least WUE $(95 \mathrm{~kg}$ $\mathrm{ha}^{-1} \mathrm{~mm}^{-1}$ ) was recorded at 1.0 Epan in tomato under sandy clay loam soil (Vijay Kumar et al., 2012) ${ }^{[42]}$.

Praharaj and Kumar (2012) $)^{[35]}$ revealed that drip fertigation in pigeonpea at both stages (branching and pod development) showed similar trend with that of seed yield. Lower water use, greater profile soil-moisture content and water-use efficiency $\left(65.1 \mathrm{~kg} \mathrm{ha}^{-1}\right.$ $\mathrm{cm}^{-1}$ ), were evident with drip fertigation at both the stages.

Vimalendran and Latha (2014) ${ }^{[43]}$ observed that surface irrigation with conventional method of fertilizer application recorded lower water use efficiency of 3.70 and 3.38 $\mathrm{kg} \mathrm{ha}^{-1} \mathrm{~mm}^{-1}$ whereas it was reverse with drip irrigation of $100 \% \mathrm{WRc}+125 \% \mathrm{RDF}$ through WSF with a WUE of $6.97 \mathrm{~kg} \mathrm{ha}^{-1}$ $\mathrm{mm}^{-1}$ during 2011-12 and during second season (2012-13), the highest WUE of 6.72 $\mathrm{kg} \mathrm{ha}^{-1} \mathrm{~mm}^{-1}$ was recorded in drip irrigation at $50 \%$ WRc along with fertigation at $125 \%$ RDF through WSF. This might be due to effective utilization of applied water.

Verughese et al., (2014) ${ }^{[41]}$ studied the effect of different irrigation and fertigation levels for cowpea (NS621) inside poly house. Four varying treatments were selected based on varying irrigation and fertigation levels. Result showed that it was sufficient to apply fertilizer through fertigation once in four days.

Ibrahim et al., (2015) $)^{[14]}$ conducted the experiment to determine the best irrigation scheduling under the proper period of injecting fertilizer through drip irrigation water in maize crop in sandy soil. Result showed that the treatment at 0.8 crop evapotranspiration with fertilizer application in $80 \%$ of the irrigation time gave the highest water productivity $\left(1.631 \mathrm{kgm}^{3}\right.$ and saved $27 \%$ of the irrigation water compared to the control treatment. Therefore, this treatment recommended to irrigate maize crops because of the water scarcity conditions of the studied area.

Praharaj et al., (2016) ${ }^{[32]}$ revealed that microirrigation technology meant for quick and immediate distribution of water delivered near the root- zone accompanied with dissolved fertilizer(s) is a boon for both appropriate utilization of precious input (water and nutrient) and their increased utilization efficiency. Micro-irrigation (drip) has also an additional advantage of reduced conveyance losses. A study conducted under a microirrigation management in summer pulses 
showed that a significant improvement in seed yield $(31 \%)$ with water saving (11\% less water use and $43.2 \%$ enhanced WUE) were recorded in summer mungbean.

Praharaj et al., (2017) ${ }^{[31]}$ observed that WUE was maximum in case of drip-fertigation at branch $\left(66.9 \mathrm{~kg} \mathrm{ha}^{-1} \mathrm{~cm}^{-1}\right)$ followed by that at both branching and pod development (65.1 $\mathrm{kgha}^{-1} \mathrm{~cm}^{-1}$ ), and the minimum efficiency being under rainfed control $\left(58.2 \mathrm{~kg} \mathrm{ha}^{-1} \mathrm{~cm}^{-}\right.$ $\left.{ }^{1}\right)$. Therefore, higher WUE in drip irrigation and low efficiency with furrow irrigation further suggest that drip system of irrigation provides ample scope to opt for alternatives to utilize scarce water resources effectively, efficiently and also for enhanced crop productivity.

Kakade et al., $(2018)^{[16]}$ reported that application of 125:100:100 per cent recommended dose of $\mathrm{N}, \mathrm{P}$ and $\mathrm{K}$ in five splits found to be best for better uptake of major nutrients, WUE and maximizing the pigeon pea productivity through fertigation.

\section{Effect of drip fertigation on quality of pigeonpea}

Deshbhratar et al., (2010) ${ }^{[8]}$ reported that interaction between sulphur and phosphorus was found to be significant on grain yield, straw yield and yield attributes characters as well as quality like crude protein percentage. At the $20 \mathrm{~kg} \mathrm{ha}^{-1}$ level of sulphur increasing level of phosphorus upto $50 \mathrm{~kg} \mathrm{ha}^{-1}$ there by increased protein $\%$ of pigeon pea after which decreasing trends were found. The mean maximum and minimum yields (grain, straw, yield attributes and quality) were recorded $S$ 20P50 and S0P0 treatment respectively.

Brar and Imas (2010) ${ }^{[6]}$ reported that application of nutrients in split doses will not only prevent nutrient losses but also will increases in efficiency. Application of adequate amount of nutrients is usually associated with increased protein content of pigeonpea.

Manikandan et al., (2015) ${ }^{[24]}$ revealed that among the drip fertigation treatments, $75 \%$ of SRDF through drip + Foliar spray of $0.5 \%$ $\mathrm{ZnSO}_{4}, 75 \%$ of SRDF through drip + Foliar spray of $100 \mathrm{ppm}$ succinic acid, $75 \%$ of SRDF through drip + Foliar spray of 100 ppm humic acid, $100 \%$ of SRDF through drip + Foliar spray of $0.5 \% \mathrm{ZnSO}_{4}, 100 \%$ of SRDF through drip + Foliar spray of 100 ppm succinic acid, $100 \%$ of SRDF through drip + Foliar spray of 100 ppm humic acid, $150 \%$ of SRDF through drip + Foliar spray of $0.5 \%$ $\mathrm{ZnSO}_{4}, 150 \%$ of SRDF through drip + Foliar spray of $100 \mathrm{ppm}$ succinic acid and $150 \%$ of SRDF through drip + Foliar spray of 100 ppm humic acid, resultant seed quality were registered higher seed physiological quality potential compared to $50 \%$ of SRDF through drip + Foliar spray of $0.5 \% \mathrm{ZnSO}_{4}, 50 \%$ of SRDF through drip + Foliar spray of 100 ppm succinic acid, $50 \%$ of SRDF through drip + Foliar spray of $100 \mathrm{ppm}$ humic acid in both crops. While all the seed quality attributes were lower in control plot (soil application of $100 \%$ SRDF) compared to drip fertigation treatments in both crops.

\section{Economics of drip fertigation}

The experiment conducted by Patel et al., (2010) ${ }^{28]}$ during kharif season in the year 2006-07 and2007-08 at Agriculture Research Station for irrigated crops at A.A.U., Thasara, Gujarat. Result showed that under drip treatment, application of $100 \%$ RDN through fertigation recorded significantly the highest seed yield and net return as well as C: B: R.

Singh et al., (2012) ${ }^{[38]}$ reported the higher net monetary returns with 100 per cent fertigation of $\mathrm{N}$ and $\mathrm{K}$ ( ₹ $36886 \mathrm{ha}^{-1}$ ) compared to 100 per cent application of fertilizers through soil application ( ₹ $31782 \mathrm{ha}^{-1}$ ). 
Praharaj et al., (2014) ${ }^{[33]}$ reported that drip fertigation at both stages (branching and pod development) also out-yielded significantly over improved practice (furrow irrigation) during the second year $(9.4 \%)$ and in pooled data $(6.3 \%)$. greater net returns $(9,700 / \mathrm{ha})$ were evident with drip fertigation at both the stages. Kakade et al. (2017) ${ }^{[17]}$ recorded the GMR, NMR and B:C ratio was found maximum with 125:100:100 per cent RDNPK treatment. Drip fertigation as well as soil application of fertilizer had no significant impact on seed index, protein content and all the quality parameters of pigeonpea. It could be concluded that application of 125:100:100 per cent recommended dose of $\mathrm{N}, \mathrm{P}$ and $\mathrm{K}$ in five splits found to be best for maximizing the yield and beneficial in increasing the productivity and economic returns of pigeonpea.

The higher net monetary returns were obtained with drip-fertigation at branching and branching + pod development. An additional net return of INR 9650/ha was realized following drip-fertigation technology applied at both critical stages in comparison to rainfed control. Consequently, higher per day profit (INR 300) and crop productivity $(13.7 \mathrm{~kg})$ were calculated under this treatment. In addition to water economy, a supplementary net return of INR 1560/ha was obtained with drip-fertigation when compared to normal furrow irrigation (improved practice). It was well-established from the present study that moderate water use under drip-fertigation at branching + pod development produced optimum/potential grain yield (3468 kg/ha) and WUE (65.1 $\mathrm{kg} / \mathrm{ha}-\mathrm{cm})$ complemented with higher net profit (INR 76,050) and agronomic efficiency. Higher net return and benefit cost ratio were also reported with drip-fertigation at Coimbatore, India reported by Praharaj et al., $(2017)^{[31]}$.
In conclusion this paper reveals that the studies on raising pigeonpea by drip fertigation leads to saving of water, fertilizers, increased yield and water use efficiency. Lot of work in drip fertigation on pigeonpea is carried out in India, but the results may vary with local agro-climatic conditions. Hence, test the drip fertigation for growing pigeonpea in their local regions, so that the locally obtained results of research work may be helpful to the farmers for increasing production, productivity and benefit.

\section{References}

1. Adhikary and Sarkar, B. K. 2000. Pigeonpea intercropping with legumes in Bihar plateau at different levels of phosphate and cropping patterns. Indian J. Agron., 45(2): 279-283.

2. Anil Jain. 2010. Revolution of drip irrigation in Maharastra-A success story. Maharastra Economic Development Council, Monthly Economic Digest. May issue, pp. 31-33.

3. Anilkumar, P. 2001. Irrigation and nitrogen management through drip fertigation in chilli. M.Sc. (Ag.) Thesis, Acharya N.G. Ranga Agri. Univ., Andhra Pradesh.

4. Anitta Fanish, S. and Muthukrishnan, P. 2013. Nutrient Distribution under Drip Fertigation Systems. World Journal of Agricultural Sciences. 9(3): 277 - 283.

5. Avnish Kumar and H.S. Kushwaha. 2006. Response of Pigeon pea (Cajanus cajan) to sources and levels of phosphorus under rainfed condition. Indian Journal of Agronomy. 51(1): 60-62.

6. Brar, M. S. and P. Imas. 2010. Potassium and crop quality. International potash Institute.

7. Chandra Shekhar, P., K. Avilkumar, M. Uma and V. Ramulu. 2014. Response of pigeon pea (Cajanus cajan L.) to different nutrigation levels. The J. Res. 
PJTSAU42 (3)71-74, 2014.

8. Deshbhratar, P.B., P.K. Singh, A.P. Jambhulkar and D.S. Ramteke. 2010. Effect of sulphur and phosphorus on yield, quality and nutrient status of pigeon pea (Cajanus cajan). Journal of Environmental Biology, 31(6) 933-937.

9. Duraisamy, V. K. and Manickasundaram, P. 2008. Agronomic management for perennial redgram through irrigation and mulching. Madras Agric. J., 95 (1-6):205207.

10. Gajera, M.S. and R.P.S. Ahlawat. 2006. Optimization of Irrigation and Evaluation of Consumptive Water Use Efficiency for Rabi Pigeon pea (Cajanus cajan (L) Millsp). Legume Res., 29 (2): 140 - 142, 2006.

11. Ghosal, S. and Bahl. 2000. Studies on the building up of soil fertility by the phosphatic fertilization on legumes. Legume Res., 23: 110-113.

12. Goud, V.V. and H.B. Kale 2010. Productivity and profitability of pigeonpea under different sources of nutrients in rainfed condition of central India. Journal of Food Legumes. 23(3\&4) 212-217.

13. Grant, C. A. D. N. Flaten, Tamasiewicz, D. J. and Sheppard, S. C. 2001. The importance of early season phosphorous nutrition. Can. J. Plant Sci., 81: 211-224.

14. Ibrahim Mohammed, M., Ahmed A. El. Baroudy and M. Ahmed. 2015. Irrigation and fertigation scheduling under drip irrigation for maize in sandy soil. International Agrophysics, 2016, 30, page: 47-55.

15. INCID. 2006. Drip irrigation-prospects and coverage in India. Indian National Committee on Irrigation and Drainage, Ministry of water resources, New Delhi.

16. Kakade, S. U., L. A. Mohurle, V. M. Bhale, J. P. Deshmukh and V. V. Gaud. 2018. Response of Split Application of Nutrients through Fertigation on Nutrients
Uptake, Nutrient and Water Use Efficiency and Yield of Pigeon pea. Int.J.Curr.Microbiol.App.Sci. Special Issue-6: 826-833.

17. Kakade, S.U., Mohurle, L.A., Deshmukh, J.P. and Chorey, A.B., 2017. Effect of Drip Fertigation on Growth, Yield and Economics of Pigeonpea, Int. J. Pure App. Biosci. 5(5): 1092-1098.

18. Kantwa, S.R., I.P.S. Ahlawat and B. Gangagaiah. 2005. Effect of land configuration, post-mansoon irrigation and phosphorus on performance of sole and inter cropped Pigeon pea (Cajanus cajan). Indian Journal of Agronomy. 50 (4): 278-280.

19. Katyal, V., K.S. Gangwar and S.K. Sharma.1999. Grain yield and phosphorus status in pigeon pea (Cajanus cajan (L) Mill sp.) - wheat (Triticum aestivum) system as influenced by level and frequency of $\mathrm{P}$ application. Ind. J. Agric. Sci., 69, 84-85.

20. Latha, K. R. Vimalendran, L. and Muthiah, AR. 2012. Feasibility studies on transplanted pigeonpea under drip fertigation in Western Zone of Tamil Nadu. In: Extended summaries. 3rd International Agronomy Congress. Nov. 26-30, 2012 New Delhi, 3:1384-1385.

21. Mahalakshmi, K., K. Avil Kumar, M.D Reddy and Uma Devi, M., 2011. Response of rabbi pigeon pea (Cajanus cajan) to different levels of drip irrigation. The Journal of Research ANGRAU.39 (4):101-103.

22. Manikandan S. and K. Sivasubramaniam. 2014. Effect of surface drip fertigation on growth and seed yield in pigeon pea (Cajanus cajan L.) C. V. VBN3. National Academy of Agricultural Sciences (NAAS).

23. Manikandan, S. and S. Sivasubramaniam. 2015. Effect of drip fertigation and sowing season on quantitative traits of pigeon pea (Cajanus cajan L.). Journal of 
Advanced Studies in Agriculture, Biological and Environmental Sciences (JABE) Vol.2, issue, 2015 (July-Sept).

24. Manikandan, S., K. Sivasubramaniam \& R. Geetha. 2015. Influence of drip fertigation on resultant seed quality in main and ratoon crops of pigeon pea (Cajanus cajan L.) Cv. VBN3. International Journal of Agricultural Science and Research (IJASR), Vol. 5, Issue 3, 315-320.

25. Muthukrishnan, P. and Anitta Fanish, S. (2011). Influence of drip fertigation on yield, water saving and water use efficiency in maize (i L.) based intercropping system. Madras Agric. J., 98 (7-9): 243-247.

26. Nazirbay, I. S. R. Evett. Y. Esanbekov. Kamilov, B. and Heng, L. 2003. Cotton and winter wheat irrigation scheduling improvements in Uzbekistan. In: Proceedings of the International Irrigation Association Technical Conference" Understanding and addressing conservation and recycled water irrigation." International Irrigation Show. CDROM, pp. 26-34.

27. Parmodh Sharma., Manoj Shukla, K., Theodore, Sammis, W and Pradip Adhikari. 2012. Nitrate- nitrogen leaching from onion bed under furrow and drip irrigation systems. Applied and Environmental Soil Science. 2012 (Article ID 650206): 1- 17.

28. Patel R. A.; Patel J.J.and A. S. Patel, 2010. Effect of spacing, drip irrigation and nitrogen levels on oil content, $\mathrm{N}$ content and uptake of late rainy season castor (Ricinus communis). J. Oilseeds Research. 27(2):144-146.

29. Patil, V.C. H.L. Halemani, S.S. Hallikeri, R.A. Nandagavi. Bandiwadder, T.T. and Kalibavi, C.M. 2008. Comparative performance of cotton hybrids and variety under drip irrigation. J. Indian Soc. Cotton Improvement. pp. 79-84.
30. Pothalkar,S.M. 2007.Physiological investigation on drought tolerance in pigeonpea (Cajanus cajan L.). Ph. D thesis. Submitted to University of Agril. Sciences, Dharwad, Karnataka. India580005

31. Praharaj, C. S., Ummed Singh, S. S. Singh and N. Kumar. 2017. Micro-irrigation in rainfed pigeon pea -Upscaling productivity under Eastern Gangetic Plains with suitable land configuration, population management and supplementary fertigation at critical stages. Current Science, vol. 112, NO. 1.

32. Praharaj, C.S., Ummed Singh, S.S. Singh, N.P. Singh and Y.S. Shivay. 2016. Supplementary and life-saving irrigation for enhancing pulses production, productivity and water-use efficiency in India. Indian Journal of Agronomy 61 (4th IAC Special issue): S249_S261 (2016).

33. Praharaj, C.S., Ummed Singh and Kalikrishna Hazra. 2014. Technological interventions for strategic management of water for conserving natural resources. (In) 6th World Congress on Conservation Agriculture-Soil Health and Wallet Wealth, Winnipeg, Manitoba, Canada, 22-26 June 2014.

34. Praharaj, C.S., 2013. Managing precious water through need based micro-irrigation in a long duration pigeon pea under Indian Plains. (In) International Conference on Policies for Water and Food Security, Cairo, Egypt during 24-26 June, ICARDA, FAO, IFAD, IDRC, CRDI and ARC, p. 4.

35. Praharaj, C.S. and Kumar Narendra. 2012. Efficient management of water and nutrients through drip-fertigation in long duration pigeon pea under Indian Plains. (In) Proceedings of Third International Agronomy Congress on Agronomy, Environment and Food Security for 21st Century, IARI, New Delhi, 26-30 November 2012, Vol. 3, pp. 819-820. 
36. Ryan, I. 2002. Efficient use of phosphate fertilizers for sustainable crop production in WANA. IMPHOS: Phosphate Newsletter pp. 2-5.

37. Snapp, S.S., R. B.Jones, E. M. Minja, J. Rusike, and S. N. Silim. 2003. Pigeon pea for Africa: A versatile vegetable and more. Hort-Sci., 38: 1073-1079.

38. Singh, B., Singh, R. and Singh, R. 2012. Improving water and nutrient use efficiency through fertigation. Indian $J$. Fert., 8(1): 94 - 103.

39. Singh, R.S. and M.K. Yadav. 2008. Effect of phosphorus and biofertilizers on growth, yield and nutrient uptake of long duration pigeon pea under rained condition. Journal of Food Legumes .21(1):46-48.

40. Tiwari, D. D. Pande, S. B. and Dubey, M. K. 2012. Effect of potassium application on yield and quality characteristics of pigeonpea (Cajanus cajan) and mustard (Brassica juncea L. Czern) crops in Central Plain Zone of Uttar Pradesh. International Potash Institute. e-ifc. No. 31, June.

41. Verughese Anu, Meera T. Balan, A. Sajana and K. P. Swetha. 2014. Cowpea inside polyhouse with varying irrigation and fertigation levels. International Journal of Engineering Research and Development, e-ISSN: 2278-067x, pISSN: 2278-800x,

42. Vijay Kumar, A. Chandra Mouli, G. Ramulu, V. and Avil Kumar, K. 2012. Effect of drip irrigation levels and mulches on growth, yield and water use efficiency of Tomato. J. Res. ANGRAU. 40 (4):73-74.

43. Vimalendran, L. and K.R. Latha. 2016. Effect of drip fertigation on nutrient uptake and seed yield of pigeon pea [Cajanus cajan (L.) Millsp.] under western agro climatic zones of Tamil Nadu. Legume Research, 39 (5) 2016: 780-785. Print ISSN: 0250-5371 / Online ISSN: 0976-0571 Agricultural Research Communicatio Centre.

44. Vimalendran, L. and Latha, K.R. 2014. Yield, water use and water use efficiency of pigeonpea [Cajanus cajan (L.) Millsp.] under drip fertigation system. Journal of Applied and Natural Science. 6 (1): 457462.

45. WRI, 2007. Annual report of world resources institute. www.wri.org/ publication/WRI-annual-report.

\section{How to cite this article:}

Thakare, S. S., L. A. Mohurle, S. U. Kakade, J. P. Deshmukh, A.N. Paslawar and Parlawar, N. D. 2020. A Review on Response of Pigeonpea to Different Drip Fertigation Levels. Int.J.Curr.Microbiol.App.Sci. 9(10): 2490-2502. doi: https://doi.org/10.20546/ijcmas.2020.910.299 